\title{
Psychosocial aspects, body composition and hemodynamics parameters in Scouts.
}

\author{
Patrícia Espíndola Mota Venâncio1; Mário Henrique Fernandes²; Viviane Soares', Iransé Oliveira-Silva1; \\ Deise Aparecida de Almeida Pires-Oliveira'; William Alves Lima'; Henrique Lima Ribeiro'; Grassyara Pinho Tolentino'.
}

\begin{abstract}
Background: In order for the activities carried out by the boy scouts to achieve the objectives foreseen in their planning, it is important to have concrete data on the physical situation of children and adolescents, such as blood pressure, knowledge of how children are related to their degree of stress, anxiety and depression. Objectives: To identify blood pressure, Body mass index (BMI), and scores of stress, anxiety and depression in boy scouts from 7 to 17 years of age from the Bernardo Sayão Scout Group of the city of Anápolis in Goiás. Material and method: Adolescents from 7 to 17 years of age of both genders. BMI data were collected and a stress, anxiety and depression questionnaire was applied and blood pressure was measured. The normality of the data was verified with the Shapiro-Wilk test. The difference between the three groups was verified by the Dunusk's post-hoc Kruskall-Wallis test. The categorical variables were analyzed by the Chi-square and the Spearman correlation coefficient verified the relationship between age and the variables Systolic Blood Pressure (SBP), Dyastolic Blood Pressure (DBP), BMI, anxiety, depression and stress. Results: The SBP of the participants in the "little wolf" category was inferior when compared to the scouts $(p<0.001)$ and senior $(p=0.004)$, and the same happened with the PAD (little wolf $x$ scout, $p=0.03$ and little wolf $x$ senior, $P=0.005$ ). An association was found between $B M I$ and sections. Most of the juniors, scouts and seniors were underweight. Among scouts children and adolescents there was a significant association with stress. In the category of the "little wolf" was found $53.60 \%$ of the children with very intense stress. The correlation between the variables SBP, DBP, BMI, anxiety, depression and stress with the age of children and adolescents. Age correlated negatively with anxiety, depression, and stress. Thus, as children are younger increases the degree of anxiety, depression and stress. Conclusion: The little wolf category had better BP results than the other categories, but they had higher levels of stress, depression and greater anxiety.
\end{abstract}

Key words: Blood Pressure, Anxiety, Depression.

\section{INTRODUCTION}

The evolution process that Brazilian society has been experiencing is making more evident the onset of diseases (e.g. cardiovascular, depression, stress, anxiety) in all age groups, from childhood to old age ${ }^{(1)}$. Studies show that the emergence of these diseases has a close relationship with the adopted lifestyle, with emphasis on the decrease of the physical activity added to the inadequate eating habits ${ }^{(2)}$.

There are recurrent studies in the literature showing relationships between two or three factors that contribute to a poor quality of life $^{(3)}$, however, there are few researches that point to several factors that young people are exposed to, which contribute to the adoption of an inadequate lifestyle, reinforcing the development of pathologies, especially hypertension, stress, anxiety and depression ${ }^{(4)}$.

All these pathologies are typical of modern society in which one lives, whose time is an aggravating for all, given the hectic life that leads to unhealthy practices such as poor diet and lack of physical activity ${ }^{(5)}$. This becomes one of the major contributors to the development of health problems, with frequent reports of problems related to blood pressure and stress ${ }^{(6,7)}$.

This problem in the circulatory system can begin in childhood or adolescence and progress slowly into adulthood, but in some cases, it manifests acutely even in youth ${ }^{(8,9)}$. And in order to combat it, it is necessary a change in the habits of life, seeking to implement actions in daily life that lead the individual, even if involuntarily, to exercise ${ }^{(4)}$.

One way to promote the practice of physical activity is to bring together children and adolescents of the same age group in Scout Groups in which activities has moderate to high intensity, always being careful and observing the individuality and the state of the physical preparation of each one of them ${ }^{(10)}$.

The aim of the Scout Movement is to make children, adolescents and young people fully integrated in intellectual,

Corresponding author: Patrícia Espíndola Mota Venâncio. Rua Leopoldo de Bulhões n.1014, Centro, CEP 75040-500- Anápolis- GO, Telephone: +55 62 992639330.

E-mail: venanciopatricia@hotmail.com

${ }^{1}$ Professor on Centro Universitário de Anápolis - UniEVANGÉLICA, Goiás (GO), Brazil.

Full list of author information is available at the end of the article.

Financial support: The authors declare there was no financial support.

Submission date 03 August 2017; Acceptance date 25 October 2017; Publication date 27 October 2017 
spiritual, social, affective and, above all, physical areas through activities experienced by games and motivational, competitive and fun songs and with the collaboration of everyone in the planning and execution process, taking into account the maturity of young people $\mathrm{e}^{(11)}$.

Scout activities especially seek, in the contact with nature, to find challenges that provide the young people to discover the balance of the body, to socially relate to others of the same age, to become more creative and to assume their protagonism before their lives, making decisions that lead them to understand the meaning of having a healthy lifestyle ${ }^{(12)}$.

In order to these activities, carried out by the Boy Scouts, achieve its objectives foreseen in their planning, it is important to have concrete data on the physical situation of children and adolescents, such as blood pressure, their degree of stress, anxiety and depression. Information that the group does not have, and that the present study seeks to find.

Understanding that these data are important for the adults responsible for the activities to know in what state they are and what effects these activities performed at the meetings leads to, the study aims to identify blood pressure, stress score, anxiety and depression in Scouts from 7 to 17 years old, of both genders, of the Bernardo Sayão Scout Group of the city of Anápolis-GO.

\section{METHODOLOGY}

It is a cross-sectional study, supported by a quantitative and descriptive approach. In this research the members of the Bernardo Sayão Scout Group, composed of a sample of 54 children and adolescents from 7 to 17 years of both genders, were subdivided into groups: 28 children and adolescents in "little wolf" (7 to 10 years), with mean age of $8.82 \pm 1.33$; 18 in "scout" (11 to 14 years), with mean age of $12.56 \pm 0.98$ and 8 in "senior" (15 to 17 years), with mean age of $16.00 \pm 0.07$.

In order to participate in the research, the following inclusion criteria were observed: registration with the Bernardo Sayão Scout Group in the Union of Scouts of Brazil in 2016, attendance at meetings, being enrolled for at least 6 months in the group and that the responsible for minors were in accordance with the Free and Informed Consent Form.

During six weekly meetings, the stress questionnaires of the "Saúde em Movimento" website were applied, composed of 23 questions about the state of the individual in the last 2 months. Assessment of anxiety and depression level was performed with Portuguese version of HAD scale (Universidade Estadual Paulista, UNESP) $)^{(13)}$ composed of 14 questions with a score of 0 to 3 , in which the even numbered questions referred to the degrees of anxiety and the odd numbered questions to the depression, and the final score from 0 to 21 scored as unlikely, possible, and probable in acquire the disease.

Blood Pressure was measured 3 times, with the evaluated at rest. The volunteers who had mean values of systolic blood pressure (SBP) were classified as hypertensive; for diastolic blood pressure (DBP) higher than the 95th percentile, the variables gender, age and height were taken into account ${ }^{(14)}$.

In addition to this, the BM was also measured by means of a mechanical platform scale from the Filizola brand, with a maximum capacity of $150 \mathrm{~kg}$ and a precision of $0.1 \mathrm{~g}$. The height (m) of each volunteer was measured with a Wiso Compact stadiometer, with a capacity of $220 \mathrm{~cm}$. The data collected regarding $\mathrm{BM}$ and height were used to calculate $\mathrm{BMI}$. Both $\mathrm{BM}$ and height were measured in duplicate and, if they found different values (i.e. $>0.05 \mathrm{~kg}$ to $\mathrm{BM}$; $>0.1 \mathrm{~cm}$ to height), a third measure was carried out, so the average of the three measures was considered. Children and adolescents were classified according to $\mathrm{BMI} / \mathrm{age}$, as proposed by Cole $\mathrm{e}^{(15)}$. This study project was approved by the Research Ethics Committee of the UniEVANGÉLICA with number 0001.403/2011.

Data were expressed as mean, standard deviation, frequencies and percentages. The normality of the data was verified with the Shapiro-Wilk test. The difference between the three groups was verified by the Kruskall-Wallis test, with Dunn's post hoc test. The categorical variables were analyzed by Chi-square, and Spearman's correlation coefficient verified the relationship between age and variables BMI, SBP, DBP, anxiety, depression and stress.

\section{RESULTS}

The characteristics of the participants are described in table 1. The SBP of the Little Wolf was lower when compared to Scout $(p<0.001)$ and to Seniors $(p=0.004)$, the same occurred with the DBP (Little Wolf $x$ Scout, $p=0.03$ and Little Wolf $x$ Seniors, $p=0.005$ ).

The anxiety scores were lower in the Scout when compared to the Little Wolf $(p=0.02)$, and for depression, the Seniors presented higher scores $(p=0.002)$.

An association was found between BMI and the categories ( $p=0.04$ ) of Scout. The majority of Little Wolf, Scout and Seniors were underweight (Table 2). In the Little Wolf group were found $53.60 \%$ of the children with very intense stress.

Table 3 shows the correlation between the variables SBP, DBP, BMI, anxiety, depression and stress with age of children and adolescents. Age correlated negatively with anxiety $(p=0.03)$, depression $(p=0.02)$ and stress $(p=0.01)$. Thus, as children are younger, the degree of anxiety, depression, and stress increases.

\section{DISCUSSION}

It was possible to verify as results that the activities developed at the end of the week, proposed by the Group of Scouts, were positive for the analyzed groups in both blood pressure and stress, adequate according to age. Fact that, in the study of Ferreira ${ }^{(16)}$ showed that of a sample of 8,661 students - since there are no studies analyzing Scouts - $79.6 \%$ of them had sedentary behavior during the weekend, of these, $50 \%$ reported that they spent more than two hours in front 
Table 1. Descriptive characteristics of participants.

\begin{tabular}{|c|c|c|c|c|}
\hline Variables & Little Wolf ( $n=28$ ) & Scout ( $n=18)$ & Senior $(n=8)$ & p \\
\hline Age (years) & $8.82(1.33)$ & $12.56(0.98)$ & $16.00(0.76)$ & $<0.001$ \\
\hline Body mass (kg) & $32.93(8.28)$ & $55.37(10.68)$ & $70.10(22.88)$ & $<0.001$ \\
\hline Height (m) & $1.37(0.10)$ & $1.62(0.08)$ & $1.74(0.04)$ & $<0.001$ \\
\hline BMI $\left(\mathrm{kg} / \mathrm{m}^{2}\right)$ & $17.39(3.29)$ & $20.87(3.15)$ & $22.97(6.90)$ & $<0.001$ \\
\hline $\mathrm{SBP}(\mathrm{mmHg})$ & $94.96(13.15)$ & $110.17(7.82)^{*}$ & $112.13(10.10)^{* *}$ & $<0.001$ \\
\hline $\mathrm{DBP}(\mathrm{mmHg})$ & $60.75(8.20)$ & $66.83(6.56)^{*}$ & $72.75(8.81)^{* *}$ & 0.002 \\
\hline Stress & $9.10(5.88)$ & $10.94(4.35)$ & $7.75(5.85)$ & 0.33 \\
\hline Anxiety & $5.89(3.81)$ & $2.61(4.13)^{*}$ & $5.25(3.92)$ & 0.03 \\
\hline Depression & $2.25(3.71)$ & $1.72(2.37)^{*}$ & $4.25(2.66)$ & 0.002 \\
\hline
\end{tabular}

Note: BMI- body mass index

Table 2. Association between the Scout category and the hemodynamic variables (body composition, anxiety, depression and stress).

\begin{tabular}{lccc}
\hline \multicolumn{1}{c}{ Variables } & Little Wolf $(\mathbf{n = 2 8 )}$ & Scout $(\mathbf{n}=\mathbf{1 8})$ & Senior $(\mathbf{n}=\mathbf{8})$ \\
\hline BMI & $19(67.90)$ & $17(94.40)$ & $07(87.50)$ \\
Low weight & $08(28.60)$ & $01(5.60)$ & $0(0)$ \\
Normal & $01(3.60)$ & $0(0)$ & $01(12.5)$ \\
Overweight & & & \\
Anxiety & $16(66.70)$ & $05(71.40)$ & $05(71.40)$ \\
Unlikely (0-7 points) & $06(25.00)$ & $01(14.30)$ & $02(28.60)$ \\
Possible (8-11 points) & $02(8.30)$ & $01(14.30)$ & $0(0)$ \\
Probable (12-21 points) & & & $07(100.00)$ \\
Depression & $18(75.00)$ & $07(100.00)$ & $0(0)$ \\
Unlikely (0-7 points) & $05(17.90)$ & $0(0)$ & $0(0)$ \\
Possible (8-11 points) & $01(3.60)$ & $0(0)$ & 0.78 \\
Probable (12-21 points) & & $11(61.10)$ & $01(12.50)$ \\
Stress & $04(14.30)$ & $02(11.10)$ & $02(25.00)$ \\
No stress & $04(14.30)$ & $02(11.10)$ & $03(37.50)$ \\
Moderate & $05(17.90)$ & $03(16.70)$ & $02(25.00)$ \\
Intense & $15(53.60)$ & & 0.02 \\
Very intense & & &
\end{tabular}

Note: BMI- Body Mass Index. ${ }^{*}$ Data to $p<0.05$.

Table 3. Spearman correlation coefficient between age and variables

\begin{tabular}{ccc}
\hline Variable & $\mathbf{r}$ & $\mathbf{p}^{*}$ \\
\hline Body mass index & 0.53 & $<0.001$ \\
Systolic blood pressure & 0.64 & $<0.001$ \\
Diastolic blood pressure & 0.48 & $<0.001$ \\
Anxiety & -0.29 & 0.03 \\
Depression & -0.33 & 0.02 \\
Stress & -0.34 & 0.01 \\
\hline
\end{tabular}

Note: *Data to $\mathrm{p}<0.05$.

of the TV; $44 \%$ spent more than two hours playing electronic games and in front of the computer were $55 \%$.

In the study of Bozza ${ }^{(17)}$ are presented data about sedentary behavior associated with hereditary factors, which increase the prevalence of altered blood pressure, influenced mainly by daily habits. These data are in agreement with those obtained in this study, since it showed that the children and adolescents evaluated, who participated in varied scouting activities and adapted to the respective age groups, presented normal blood pressure for the ages, and as the children grow and become more active and independent, blood pressure and stress tend to stabilize at an ideal level for the age.

Lombardi ${ }^{(18)}$ reported in their study that they used anthropometric variables, eating habits and habitual practice of physical activity, noting that only abdominal circumference was associated with high blood pressure, however, in the present study, the data showed that the children and adolescents evaluated had positive results to the blood pressure, leading to believe that the physical activity practiced, 
even on weekends, contributes to the maintenance of the pressure force.

As could be observed in the study of Barbosa(19) the sedentary habits are already inserted in the daily context of the life of the children and adolescents since they enter the school, either by the lack of structure for physical activities, by the teaching program adopted by the school and even by the social context. All of this contributes to the data described in this study and reinforces the need for extra activity, such as those practiced by Scouts, which contribute positively, as observed, to a healthier life and decrease in the short, medium and long term the incidence of hypertension and stress that increasingly tends to appear early in young people and extends into adulthood, worsening(20).

As for the stress factor, Lopes ${ }^{(21)}$ identified in their research that, among the common disorders, there is stress in children and adolescents, which progressively has a higher incidence in older adolescents of both sexes. These information contributes to the positive aspect of the practice of scouting, in which the evaluated ones showed a compatible classification of stress for the age group. Thus, was observed that stress tends to be more controlled in older adolescents, different from what was observed by the researchers above, showing that the practice of the appropriate physical activity to the individual, performed in a pleasant way can bring positive results to practitioners.

In view of these results, further studies are needed, since this work is a pioneer, thus making it difficult to have a more in-depth discussion. It is of paramount importance to improve the results developed in this research, judging by the fact that there is no study of the peculiarities of physical activities in the health, well-being and educational field of the practitioners of Scouting.

\section{CONCLUSION}

In view of the evidence presented, it is possible to conclude that the profile of the children and adolescents practicing the scouting activities of the Bernardo Sayão Group are individuals who, even though they presented a BMI below normal, all other variables studied did not present significant differences for the categories / age groups, which may be the result of the practice of the weekly activities performed with these young people.

A relevant data, for future studies to explore, was the fact that youngsters presented lower levels of stress, depression and anxiety than older ones. A triggering factor for this data may be that there is a possible influence of the activities carried out by the Scouts, since, as these youngsters get more contact with the Scouts, the stress, depression and anxiety index decrease. This is a data of great relevance for developing studies with the practitioners of scouting, and can generate new parameters related to the physical, mental and educational health of this modality practiced so many years in the country.

\section{AUTHOR'S CONTRIBUTION}

PEMV: study design, interpretation of results, writing of the manuscript. MHF: data collection and interpretation of results, writing of the manuscript. VS: analysis of data and interpretation of results, writing of the manuscript. IOS, DAAPO, WAL, HLR: writing of the manuscript. GPT: review of all manuscripts, study design, writing of the manuscript.

\section{CONFLICTS OF INTEREST}

The author(s) declare that they have no competing interests.

\section{AUTHOR DETAILS}

${ }^{2}$ Student on Physical Education School at University Center of Anápolis (UNIEVANGÉLICA), Goiás (GO), Brazil.

\section{REFERENCES}

1. ABELHA L. Depressão, uma questão de saúde pública. Cad. Saúde Colet., Rio de Janeiro, 2014;22(3):223.

2. RESENDE MH; FURLANETTO JÚNIOR R; GONÇALVES A. Fatores de risco para doenças cardiovasculares em crianças de 6 a 12 anos. Revista Digital. Buenos Aires. 2012; 17(173).

3. FREITAS D; RODRIGUES CS; YAGUI CM; CARVALHO RST; MARCHIALVES LM. Fatores de risco para hipertensão arterial entre estudantes do ensino médio. Acta Paul Enferm. 2012;25:430-4.

4. SANTOS JBG; GONÇALVES TS; LIMA RF; CRENITTE PAP. Suggestive signs of stress in school children with learning disabilities. Revista CEFAC, 2016;18(4):854-63.

5. PINOTTI S; DE FÁTIMA MM; MORGANA G. Percepção sobre a hipertensão arterial e qualidade de vida: contribuição para o cuidado de enfermagem. Cogitare enfermagem. 2008;13(4):566-34.

6. TELES JA; COSTA KM; LAUTNER MAFA; LAUTNER RQ. Índice de prevalência de obesidade e hipertensão em crianças e pré adolescentes no ensino público de Formiga-MG. Enfermagem Revista. 2013;15(3):297307.

7. MARÇAL PA; ÁVILA AA. Estresse no trabalho e hipertensão arterial em profissionais de enfermagem da rede municipal de saúde de Belo Horizonte, Minas Gerais, Brasil. Revista Brasileira de Saúde Ocupacional. 2016;41: e6.

8. SILVA SSBE; OLIVEIRA SFSB; PIERIN AMG. O controle da hipertensão arterial em mulheres e homens: uma análise comparativa. Revista da Escola de Enfermagem da USP, São Paulo; 2016;50(1):50-8.

9. Fernandes, R. A., Sponton, C. H. G., \& Zanesco, A. Atividade física na infância e adolescência promove efeitos benéficos na saúde de adultos. Rev SOCERJ. 2009;22(6): 365-72.

10. UNIÃO DOS ESCOTEIROS DO BRASIL (a). Princípios, organização e regras. 10a edição. Curitiba: Escritório Nacional; 2013:24.

11. UNIÃO DOS ESCOTEIROS DO BRASIL (b). Programa de Jovens: Objetivos finais e intermediários. Curitiba: Escritório Nacional; 2016:4.

12. UNIÃO DOS ESCOTEIROS DO BRASIL (c). Projeto educativo do movimento escoteiro. Curitiba, Escritório Nacional; 2016:4-16.

13. AGUIAR F. ESCALA HAD - AVALIAÇÃO DO NÍVEL DE ANSIEDADE E DEPRESSÃO. UNESP. [fmb.unesp.br/Home/Departamentos/ Neurologia.../ViverBem/had_com_escore.pdf].

14. CHOBANIAN, A.V.; BAKRIS, G. L.; BLACK, H.R.; CUSHMAN, W. C.; GREEN, L.A.; IZZO, J.L. Seventh report of the Joint National Committee on Prevention, Detection, Evaluation, and Treatment of High Blood Pressure. Hypertension. 2003;42(6):1206-52.

15. COLE, T.J.; BELLIZZI, M. C.; FLEGAL, K. M.; DIETZ, W.H. Establishing a standart definition of cihild overwight and obesity worlwide: international survey. BMJ. 2000;320(6). 
16. Ferreira RW, Rombaldi AJ, Ricardo LIC, Hallal PC, Azevedo MR. Prevalência de comportamento sedentário de escolares e fatores associados. Revista Paulista de Pediatria. 2016;34(1):56-63.

17. Bozza R, Campos W, Filho VCB, Neto AS, Silva MP, Maziero RSB. Pressão Arterial Alterada em Adolescentes de Curitiba: Prevalência e Fatores Associados. Arq Bras Cardiol. 2016;106(5):411-418.

18. Lombardi G, Fernandes RA, Christofaro DD, Casonatto J. Prática habitual de atividade física, hábitos alimentares, modulação autonômica e indicadores antropométricos estão associados à prevalência de pressão arterial elevada?. Journal of Physical Education, 2016;27(1):2734.
19. Barbosa SC, Coledam DHC, Neto AS, Elias RGM, Oliveira AR. Ambiente escolar, comportamento sedentário e atividade física em pré-escolares. Revista Paulista de Pediatria. 2016;34(3):301-8.

20. FARIA PA. Relato de experiência: Métodos de captação de pacientes hipertensos na PMF Vila Ipiranga. 2017

21. Lopes CS, Abreu GA, Santos DF, Menezes PR, Carvalho KMB, Cunha CF, Vasconcellos MTL, Szklo M. ERICA: prevalência de transtornos mentais comuns em adolescentes brasileiros. Revista de Saúde Pública. 2016;50(1):14 